\title{
Luther és Kálvin jogfilozófiai és politikai filozófiai nézetei
}

\author{
Recenzió a Reformáció, államhatalom, politika \\ címú kötetról
}

\section{The Legal and Political Philosophy of Luther and Calvin \\ Review by Book Entitled Reformation, State Power and Politics}

ÖSSZEFOGLALÁS

Luther és Kálvin munkásságának hatása a modern kor embere számára megkerülhetetlen. Ez a megállapítás azonban nem csupán a vallást, illetve a teológiát illetốen igaz, de a politika, az állam és a jog területét illetôen is. Az itt ismertetett kötet a két nagy reformátor utóbbiak kapcsán képviselt gondolatait mutatja be.

Kulcsszavak: Luther, Kálvin, reformáció, teológia, jog, politika, világi felsőbbség

\section{Summary}

The impact of the two reformers, Luther and Calvin is unavoidable for the people of the Modern Age. This statement, however, is true not only in terms of religion and theology but also in the field of politics, government and law. The volume introduces the thoughts of these two significant reformers from the above-mentioned point of view.

Keywords: Luther, Calvin, reformation, theology, law, politics, worldly superiority 
Birkás Antal a Reformáció, államhatalom, politika címú könyv megírása során nem kisebb feladatra vállalkozott, mint a két nagy reformátor, Luther és Kálvin gondolatvilágának és nézeteinek - egy pontosan meghatározott szempontrendszer alapján történố - összehasonlító vizsgálatára a „protestáns politikai filozófia” tárgykörében. A szerzô tudományos kutatásai ugyan messzebbre nyúlnak vissza, de az ebben a kiadványban lefektetett gondolatok és elemzési szempontok 2017-ben részét képezték annak a habilitációs eljárási folyamatnak, amely kiegészült a „protestáns szociáletika”, valamint az állam és egyház viszonyát vizsgáló kutatási eredményekkel. Így a könyvben kifejtett jogfilozófiai és politikai filozófiai öszszehasonlítás nem csupán a reformáció 500. évfordulója kapcsán kerülhet ismét a középpontba, de számos kérdést és problémakört felvet, amely a mindenkori olvasót további gondolkodásra készteti, hiszen a szerzó tágabban a keresztény ember világi felsôbbséghez fúzốdô kapcsolatának vizsgálatát túzte ki célul.

A könyv borítóján szereplô Luther- és Kálvin-ábrázolás egymás mellé helyezése sem véletlen, a kiadvány szándéka szerint mindkét reformátor nézeteinek kifejtése ugyanakkora hangsúllyal szerepel. Mint ahogyan a hátoldalon feltüntetett rövid, ám figyelemfelkeltô leírás, Szászfalvi László ajánló sorai is mutatják: „A két nagy reformátor gondolkodása messze túlnyúlik a teológia határain. Luther és Kálvin hatása a politika, a gazdaság, a jogtudomány, a zene, a modern természettudomány kibontakozása, illetve átalakulása terén is tetten érhetô. Ez a könyv a hatalom és a politika, az állam és a jog világával kapcsolatos reformátori gondolatokat igyekszik meglehetôs alapossággal feltárni." Ennek megfelelôen az ajánlás után két idézettel indít a könyv. Dr. Masznyik Endre a wittenbergi teológust méltatja: „Az emberiség történetének páratlan szellemóriása", míg Jean-Jacques Rousseau szavai a genfi reformátorról így csengenek: „Akik csak teológust látnak Kálvinban, azok félreismerik lángelméjének nagyságát." Komoly várakozással tekinthet az olvasó a könyv további részei elé, hiszen a szerzó intenciója szerint egyiket sem helyezi a másik fölé; Birkás Antal a bevezetésben a kutatási idôszak bemutatásán túl kulcsot ad a témaválasztásához. „Külön-külön számos tanulmány látott napvilágot az általam körbejárt dimenziók egy részében, azonban így, kettejüknek e témába vágó gondolatait együttesen kevesen elemezték, fốként nem olyan széles szempontrendszer alapján, mint amelyeket könyvem második nagy fejezete felvonultat." Vezérelvként két célt tár elénk: az egyik az emlékállítás, a másik annak bemutatása, milyen hatást gyakoroltak a jog és politika világára. A protestantizmus közélet iránti fogékonyságának igazolását is látja ebben, „saját múltunk és jelenünk, Európa történetének megértése szempontjából megkerülhetetlen" - fogalmaz a könyv írója. A kiadvány négy nagyobb fejezeten keresztül tárgyalja a gondolatkört, szerkesztése tudatos és igen fegyelmezett hozzáállást mutat. A kötetet epilógus és irodalomjegyzék zárja.

Az elsố nagy fejezet a Luther és Kálvin kora címet viseli. Történeti szempontból igen szerteágazó lett volna ez a bemutatás, ha kronológiai vagy akár térségekhez kötött elemzésre helyezi a hangsúlyt. Az eredeti célt szem elốtt tartva a szerzô négy szempontrendszert adott meg, amely bevallása szerint önkényes választás, de módszertani szempontból nem tartja hi- 
bának - helytálló döntésnek bizonyul. Így sikerül „mederben tartani” az eredeti témát, nagy erénye, hogy pont annyit és ott közöl a szerzô, ahol az szükséges a további megértéshez.

Az elsố értelmezési irány a teológiai kontextus, ahol a reformáció teológiai kérügmájáról (üzenetérôl) olvashatunk közérthetô formában, mellyel kulcsot kapunk a további megértéshez. Ezután az egyház helyzetérôl ad képet a szerzô, majd a reformátorok korának teológiai áramlatait ismerteti, köztük Arisztotelész, Aquinói Szent Tamás, Duns Scotus, illetve Rimini Gergely hatására hívja fel a figyelmet. A második értelmezési irány a politikai kontextus. A szerzố logikus érvrendszert állít fel annak alátámasztására, hogy a korban Európa szellemi-lelki egysége jelen volt, ugyanakkor a reformáció befolyással bírt az uralkodó hatalma, illetve a központi kormányzatok közötti kapcsolatra. Érdekes modelleket rajzol azzal összefüggésben, hogy a vallási forradalom hatott-e a politikai berendezkedés megváltozására, vagy a politikai függetlenedés vágya (ti. a pápától való függés lazulása) eredményezett vallási forradalmat. Harmadik szempontként, Változó világkép, változó világrend alcím alatt, a korszak világképét befolyásoló tényezôk közül az Oszmán Birodalom és a földrajzi felfedezések befolyásoló hatását ismerteti, végül a humanizmus rövid bemutatásával zárja, megemlítve a könyvnyomtatás elterjedésének kulcsszerepét.

A könyv második nagy fejezete a $L u$ ther nézetei címet viseli. A szerzó 11 pontos szempontrendszert állított fel alfejezetekbe rendezve a téma tárgyalására, amely a késốbbiekben alkalmassá válhat Kálvin nézeteinek bemutatására is. Vá- lasztását, annak szubjektív voltát Birkás Antal észszerúen indokolja: „teoretikusan mindenképpen támogatja az a meglátás, amely szerint a politikai filozófiának az az alapkérdése, amely a tekintély igazolásával és az engedelmességgel foglalkozik, a szempontrendszer ilyen jellegú kialakítását igazolja - legalábbis részben. E kategóriák egy kibontakozó államelméleti, jogelméleti, politikai filozófiai, etikai, természetesen teológiai dimenzió és értelmezési keret határköveit és fôbb elemeit jelölik."

A felsôbbség és annak szükségszerúsége cím alatt a felsốbbség hatalmának eredetét és szerepét tárgyalja. Luther számára a hatalom és mindaz, ami a hatalmat megjeleníti, Istentôl eredố és szükséges. A kettôs kormányzat elméletéról szólva megjelenik a „kard hatalma” és ezzel kapcsolatban Isten szerepe, válasza: „az evangélium útja, illetve a kard, a felsôbbség útja." A kormányzat felett is Isten az úr („felülrốl származtatott szuveneritás”): „Isten jobb kezével a benne hívốket kormányozza az evangélium által, míg a bal kezével a benne nem hívốket kormányozza a »jog által, $\mathrm{s}$ ha kell, annak kényszerítô ereje által «- miként azt C. G. Schweitzer írja." A kötet különösen gazdag a hermeneutikai értelmezési szempont érvényesítésében, így nem csupán a fentebb idézett szerzôtôl hoz példát, hanem Abraham Kuypertôl kezdve, Ebelingen, Ebensteinen vagy Gritschen át Boleratzky Lóránd gondolatáig számos megállapítást vesz górcsố alá egy-egy kérdés árnyaltabb bemutatásakor. Zárásként a világi kormányzat szerepéról szól: ha a felsôbbség (itt kormányzat) Istent szolgálja az emberek javára, akkor az Isten rendje szerint való. A megállapítás Kálvin nézeteinek vizsgálata kapcsán válik érde- 
kessé, hiszen a kormányzat, mindenkori politikai berendezkedés az emberek és a „felsôbbség” kapcsolatrendszerében nála is sok ponton hasonlóságot mutat.

A második szempont a Világi hatalom lelki hatalom: a két birodalom egymáshoz való viszonya címet viseli. Luther a két „birodalmat" (más helyütt kormányzat kifejezéssel fordítva) Isten kormányzatának két dimenziójaként értelmezi, amelyek eltérnek egymástól. Számos Luthertôl származó gondolat elemzése mutatja be, hogy felfogását az idố múlásával nem mindig következetesen képviselte. Birkás Antal finoman jelzi azt a változást, amely idôvel az öreg Luther gondolatvilágában bekövetkezett, nem hallgatva el, hogy a reformátor „saját korának gyermeke”, röviden utalva antijudaizmusára is.

A kötet $A$ keresztyének és a politikai autoritás cím alatt tárgyalja Luther nézeteit. Ezek meglehetôsen biblikusak, a reformátor a sola Scriptura elvéhez ragaszkodik. Az engedelmesség és az ellenállás kérdése szakasz terjedelmesebben foglalkozik a problémakörrel. Ebben szól az engedelmesség, majd az ellenállás kérdéséról. Azt a három alapesetet veszik sorra, amikor a hierarchiában alacsonyabban álló küzd rangban és erôben felette álló ellen, egyenrangúak egymás ellen, illetve a magasabban álló küzd rangban és erôben alatta lévôvel. Izgalmassá válik, s indokolt is a részletes kifejtés, ha figyelembe vesszük, hogy Luther nem csupán bibliai szakaszokkal támasztotta alá ezt a gondolatkört, hanem korának fejedelmét, elsôsorban Bölcs Frigyest helyezi példaként maga elé, s a történelmi eseményeket vizsgálva még az önvédelemból indított katonai támadásokra is részletes okfejtést adott a kor katonáinak. Így adott esetben az ellenállás kérdése is indokolttá válhat. A Luther felfogásában bekövetkezett változások zárják a gondolatmenetet, bemutatva, hogy az 1530 és 1539 közötti idôszakban zajló események miként módosították a nézeteit.

A Jog és törvény, törvény és evangélium címú szakasz körüljárja Luther jogászságról alkotott felfogását, valamint a jogról és jogtudományról vallott nézeteit. Luther elsôsorban teológus, így a jogászokról - elsôsorban az egyházjogról - lesújtó véleménnyel van. A jogról vallott felfogását a kötet szerzôje négy fố dimenzió mentén, elsôsorban Frivaldszky János munkái alapján vizsgálja: miként vélekedik Luther a jog mint Istentôl rendelt intézmény szerepérôl, a jogról mint büntetôeszközről, bemutatja a jog és a két kormányzat elméletét, és elénk tárja a természetjog - „az ész vezette" jogfelfogás - kérdéseit. Zárásként a szerzô a világi és egyházi jog, valamint a törvény és evangélium kapcsolatát vizsgálja. Figyelembe véve, hogy Luther maga is tanácsolta pogány szerzók olvasását, ha a jogban való jártasságra kíván szert tenni az ember, miután ô maga teológusként nem tud ebben kellố alapossággal nyilatkozni, akkor figyelemre méltóvá válik a kormányzat múködésének jogi háttere. Kálvin - a következô nagy fejezetben tárgyalt nézeteiben - a bibliai alapok mellett szintén korának törvényeit vette figyelembe. A kötet szerzóje tehát olyan, a kormányzat múködéséhez elengedhetetlen szempontokat, alapvetéseket vázol fel, amelyek elôremutatnak, hiszen Luther számára a jog és törvény célja a rend megteremtése és fenntartása a világban.

$\mathrm{Az}$ államforma kérdése Donald Sinnema megállapításaira is reflektál. Luther a politikáról szólva megállapítja, hogy az keresztyéni módon végzett munka, a jó- 
zan ész és szeretet múve kell hogy legyen. Így a Krisztusi uralomgyakorlás: A keresztyén uralkodó szakaszban a királytükör múfajából merítve határozza meg a jó uralkodóval szembeni elvárásokat, ám mind közül a legfontosabb az, hogy Istennel kapcsolatban áll. A keresztyén állam: álom vagy lehetséges valóság? címú fejezet a modern politikai berendezkedések múködését tekintve is figyelmet érdemel. Rendkívül izgalmas, miként is vélekedünk a lutheri gondolatokról a további évszázadok eseményeit figyelembe véve. A Politikai millenarizmus, valamint A semlegesség kérdése szakaszok egészen a jelenkorig kalauzolnak bennünket, a probléma sokszínúségét tekintve. Üdítô példaként Münster királyságát veszi példaként Luther azzal a megállapítással, hogy csupán hitbéli alapokon nem szervezôdhet politikai rend, ha az nélkülözi a törvényeket. Kálvin hasonlóan fontosnak tartotta az emberek óvását a radikális elhajlásoktól, ugyanis ezek nem Istentôl rendeltek. Egy lábjegyzet erejéig a kötet kitér a nyugati kultúra és az iszlám modell fejlődésének eltérô vonásaira, mely mögött máig érvényes, továbbgondolásra alkalmas problémakör húzódik. Luther a semlegesség kérdésében, a kor viszonyait figyelembe véve, nem tekinthetô forrásnak, fogalmi szinten vizsgálni Luther 16. századi felfogását az állami semlegesség kérdésérôl abszurd, véli a könyv szerzóje. Ugyanakkor, mint azt habilitációs téziseiben kifejtette: „Meggyôzôdésem, hogy a kettôs kormányzat felfogása az államra nézve a lelkiismereti kérdésekben tartózkodást, és ennek következményeként egyfajta »semlegességet« kell hogy eredményezzen, még akkor is, ha tudjuk jól, hogy az állam nem légüres térben, értékektôl mentes vákuumban létezik” (Birkás, 2017).
A könyv harmadik nagy fejezete Kálvin nézetei címmel az előzőhöz hasonló szempontrendszer alapján vezeti végig munkásságának eszmei hátterét. Valóban történt szelekció - ahogyan a könyvíró fogalmaz, „feláldoztam Kálvint” -, ám az eredeti célkitûzést szem elôtt tartva csakis így maradhatott meg az a keretrendszer, ami a két reformátor nézeteinek stabil összehasonlítását adja. A felsöbbség és annak szükségszerúsége alfejezetben az egyik leglényegesebb kijelentés Kónya István gondolatából kiindulva, hogy a kálvinizmusban egyszerre van jelen az isteni és az emberi mozzanat. Vagyis felülrôl származtatott szuverenitásról szól a genfi reformátor, ahol a mindenható Isten végtelen szuverenitásából fakad minden földi hatalom, tekintély, törvény, az ember pedig az isteni kegyelmet kéri és óhajtja. Míg Luther a világi kormányzattal kapcsolatban fejedelemben, felsôbbségben és alattvalókban gondolkodott, addig Kálvin szóhasználata a tisztségviselôk - akik szintén Isten kegyelméból végzik munkájukat - és politikai kormányzat terminusokon alapul. Utóbbi, vagyis a világi kormányzat szintén Isten uralmának egyik formája. A könyv második felében válik izgalmassá, hogy az elôzetesen megismert Luther-féle állásfoglalásokhoz képest Kálvin miként reagált korának problémáira ugyanazokon a kapcsolódási pontokon. Három teológiai kiindulópont vizsgálatával kezdi a szerzô: „1. Antropológiai látásmód (az ember 'imperfekt' búnös volta, melynek velejárója és következménye a hatalomnak mint olyannak a szükségszerúsége; 2. Az Újszövetség tanítása a belsố és a külsố emberrôl. Pál e tanítása fontos a világi és lelki hatalom illetékességi és hatókörével kapcsolatos kálvini felfogásban; 3. Lényeges 


\section{Tudományos múhely}

Isten mindenekfelett való szuverenitása és Kálvin ebbe vetett hite, amely magában foglalja Istennek (Krisztusnak) a világ és történelem uraként való elfogadását is." A világi és a lelki hatalom egymáshoz fúzôdô viszonyával kapcsolatos nézeteit az alábbi szempontokon keresztül vizsgálja: a jogi hagyomány, illetve saját korának jogi tanítása hogyan befolyásolta a genfi reformátor látásmódját, valamint miként jelentkezik a kálvini nézetekben a büntetôjogi jellegú jogfelfogás. Kálvin elsôsorban jogászi szemmel közelít a világi kormányzat múködéséhez, de nem hagyható ki a két birodalom egymáshoz való viszonyában az az elv, miszerint a világi kormányzatnak isteni küldetése, magasztos hivatása van. Ily módon a Keresztyének és a politikai autoritás alfejezetben a politikai hivatással összefüggố hivatásoknak is helye van, ezeket Isten rendkívül módon felmagasztalja. Hiszen az ember közösségi életre teremtetett, és az egymásrautaltságból következik, hogy a politikai kormányzatnak (regni civilis, más fordításban s a könyvben helyenként polgári kormányzatként) a közösséget kell szolgálnia, a közösségi ügyekért felelôsséget kell vállalnia. A jog és törvény, törvény és evangélium témájának vizsgálatakor az Institutio vonatkozó szakaszait elemzi. Bár Kálvin meglátásai sok ponton hasonlóak Lutheréhez, más módon közelíti a viszonyrendszer problémáját. Luther a törvényt és az evangéliumot egymás kontrasztjaként látja, Kálvin viszont nem csupán büntetô jellegú funkcióról beszél. Szerinte - a kiválasztott nép történetén keresztül bemutatva - azért történt szövetségkötés, és kapott törvényt Izrael népe, hogy azokat a kötelezettségeket megtartsa, s a szövetség erôs maradjon. Az erkölcsi törvények, az állami törvé- nyek, a szertartási törvények, valamint a mózesi értelmú „törvénykezési” törvények széles skáláján keresztül nyerhetünk betekintést Kálvin törvényekkel kapcsolatos nézeteibe. Ugyanakkor az Evangélium és politika kapcsán, mintegy közös kapcsolódási pontként, Luther és Kálvin gondolatainak egyik fontos megállapítását teszi a szerzô: „Bár a teológiának és magának az evangéliumnak is van mondanivalója a világi hatalmat birtoklók számára, de az nem kínálhat mindig és minden helyzetben tökéletes megoldást a politikai élet dilemmáira." Hiszen a politika a józan észnek alávetett. Kálvin az államformák esetében is hangsúlyozza, hogy a hatalom birtokosa Isten kegyelméból uralkodik. Annak megnyilvánulási formái a monarchikus berendezkedés, demokratikus uralom vagy arisztokratikus köztársaság, amelyek esetében lényeges, hogy Isten önmaga szuverenitását mindig emberek, egyes személyek által gyakorolja.

Birkás Antal könyvében komplex elemzési rendszerben, fegyelmezetten, mégis példákban gazdagon - a reformátorok gondolataival alátámasztva - mutatja be Luther és Kálvin nézeteinek azonosságait és eltéréseit. A kötet egyedülálló és különleges azért is, mert az utolsó nagy fejezet, A hagyaték azokat a hatásokat vizsgálja, amelyek a két reformátor gondolataiból, tetteiból következtek, s az élet számos területén, a múvészettôl a tudományokon át a gazdasági, politikai gondolkodásig formálták az egész nyugati civilizációt. A gazdasági dimenzió és politikai gondolkodás mellett a lutheri kettôs birodalom elméletének késóbbi kritikája, a demokráciáról, közösségi politikáról vallott felfogásuk színesítik, gazdagítják a korábban róluk alkotott képet. A szerzó utolsó vizsgálódási pontja, a Luther és Kál- 
vin, illetve a protestantizmus hozzájárulása az alkotmányeszme megszületéséhez alfejezetben fôként kálvini dimenzión keresztül ad kerek egységet s egyben zárást a hiánypótló kiadványnak.

A kiadvány témája ellenére lenyúgözóen részletgazdag, lebilincselő olvasmány. A mindenkori szakmában jártas befogadóréteg mellett bátran kezébe veheti a laikus olvasóközönség is. A Reformáció, államhatalom, politika címú könyv jó szívvel ajánlható, hiszen nem csupán jogi, teológiai szakkönyv, de a történelem, irodalomtörténet iránt érdeklődôk s a jelenkor eseményeinek értelmezésére fogékony olvasók is gazdagodhatnak általa.

Birkás Antal: Reformáció, államhatalom, politika. Luther és Kálvin jogfilozófiai és politikai filozófiai nézetei. Luther Kiadó, Budapest, 2011, 160 oldal.

\section{FELHASZNÁLT IRODALOM}

Birkás Antal (2017): Habilitációs tézisfüzet - fôbb tudományos megállapítások és kutatások a PhD-fokozat megszerzése óta. Budapest, www. kre.hu/ajk/images/doc4/JDI/habilitacio/ Habilitacios_tezisfuzet.pdf. 